\title{
Assessing the Indonesian General Election 2019: Election and Human Rights Relations
}

\author{
Tri Sulistyowati ${ }^{1}$, Zulkifli Aspan ${ }^{2}$ \\ \{trisulistyowati98@yahoo.com ulkifliaspan@gmail.com $\left.{ }^{2}\right\}$ \\ Trisakti University ${ }^{1}$, Hasanuddin University ${ }^{2}$
}

\begin{abstract}
In the 2019, legislative elections and the elections that will take place in 2018 in several regions there are debates that arise at this time, namely the rights of suspects and former prisoners to run for candidates for legislative and regional head candidates. On the one hand, it is the right of the suspects and the prisoners to take part in the election process, but on the other hand, there is the right of the people who must also be protected to get their representatives with their criminal records. As it turns out in practice, however, the problem is whether the suspect of corruption case, (in the name of equality before the law and the name of equality of human rights), still have a suffrage? There are two parties whose rights should be protected, namely suspects based on the principle of presumption of innocence and the rights of the people to have a clean and integrity leaders and people's representative. These problems are needed to learn in terms of Indonesian national legal provisions and international human rights provisions.
\end{abstract}

Keywords: Election, Human Rights, Constitutional Rights.

\section{Introduction}

Indonesia is a constitutional State. This has been clearly stated in Article 1 paragraph (3) of the 1945 Constitution of the State of the Republic of Indonesia. In a constitutional State, restrictions on the power of State and political must be made clearly that no one can violate. Therefore, in a constitutional State, the law plays a very important role and above the power of State and politics. Hence, it come the term "government under the law". 1

The entrenchment of democratic rights and political reform will be a second major challenge for the government. ${ }^{2}$ The period of Indonesian constitutionality expand normative facts, that the reform era gives big expectation for the renewal of State administration in order to deliver the Indonesian into a democratic constitutional State. One of them is through the implementation of general election in Indonesia.

In general, elections are the only means for the people to determine who will be elected as the leader of the country and who will be elected as the people's representatives who will sit in

${ }^{1}$ Surbakti, R. (2014). Understanding the Flaws in Indonesia's Electoral Democracy, dalam Strategic Review, The Indonesian Journal of Leadership, Policy and World Affairs, Volume 4, Number 1 January-March 2014.

2 Aspinall, E., \& Mietzner, M. (Eds.). (2010). Problems of democratization in Indonesia: elections, institutions and society. The National Bureau of Asian Research. Institute of Southeast Asian Studies, p. 13. 
the legislative body. Therefore, the Election becomes an obligation for the state to implement it. However, in the concept of a democratic state, human rights and elections are important elements that must exist. In accordance with the provisions of Article 22E of the 1945 Constitution, that General election shall be held directly, publicly, freely, secretly, fairly, and justly once in five years.

In practice, general elections must be held periodically or periodically, so that democracy can be guaranteed regularly and continuously. The implementation of elections in each country is determined based on the needs of each country. There are countries that determine that elections are held once in five years like Indonesia, and there are also countries like the United States that determine the election of the president and vice president within four years. In addition, countries that adopt a parliamentary system of government, general elections can also be held more often according to needs. With this legal construction, it can be concluded that the relation of elections is one of the very principles means of channeling citizens' rights (look at the Article 28E of the 1945 Constitution).

Hence, in the framework of implementing the human rights, it is imperative for the government to guarantee the implementation of general elections in accordance with the determined state administration schedule. In accordance with the principle of popular sovereignty where the people are sovereign, all aspects of organizing the general election must also be returned to the people to determine it. Likewise, the state must ensure that the rights of every citizen to participate in elections are protected by law, even guaranteed in the 1945 Constitution as a constitutional right.

As it turns out in practice, however, it has certain weaknesses, particularly in view of the accountability and legitimacy aspects of its establishment. In the 2019 legislative elections and the elections that will take place in 2018 in several regions there are debates that arise at this time, namely the rights of suspects and former prisoners to run for candidates for legislative and regional head candidates. Even the decision of the General Election Commission (hereinafter, KPU) to issue a KPU Regulation that prohibits former prisoners of corruption cases from being nominated as legislative candidates has drawn controversy. The Indonesian House of Representatives as the legislative body also disagrees with this limitation. Therefore, it is very interesting to do a juridical study, especially a review of aspects of human rights.

Above all, on the one hand, it is the right of the suspects and the prisoners to take part in the election process, but on the other hand, there is the right of the people who must also be protected to get their representatives who sit in the legislative and regional leaders who are clean without criminal records. Is this in accordance with the purpose of the provisions of Article 28J of the 1945 Constitution? However, as a constitutional state, every act or policy made by the organizer must be based on the law.

\section{The Indonesian General Election as A Manifestation of Human Rights}

Normatively, the provisions of Article 22E of the 1945 Constitution of the State of the Republic of Indonesia declare that general elections held in direct, general, independent, secret, honest and fair every five years held to elect members of the House of Representative, Regional Representative Board and Regional House of Representatives as organized by an 
election commission that is national, permanent, and independent. ${ }^{3}$ General elections are complex activities involving multiple parties. Not only voters, electoral participant and/or candidate, electoral organizer and government (central and local), it also involves election observers (domestic and international), civil society organizations, law enforcer, procurement and distribution partners of electoral logistics, and mass media. Since the election is a process of converting the people vote to the seat of State organizers, and the election participants (political parties and proposed candidates and/or individuals) who fight to obtain and fill the seat of State organizer, the election results in winning and loser participants.

The electoral process is vulnerable to irregularities, temptations and potentially hijacked by irresponsible individuals. At the same time, there is great expectation from the public that elections are held with integrity. The choice of a particular electoral system will also be a measure of the extent of consistency in the realization of the sovereignty of people in the 1945 Constitution. The greater of electoral system to provide a wide space for the people to decide, then the electoral system will be closer to the nature of popular sovereignty. ${ }^{4}$ If the electoral system narrows the space for the people to make their choice, then the electoral system will be further away from the nature of sovereignty contained by the 1945 Constitution.

The General Election is a manifestation of the political rights of the people to determine the course of government and the functions of the State guaranteed by the constitution. These political rights are the fundamental rights of the people. Therefore, the implementation of the General Election, in addition to embodying the sovereignty of the people, is also a means of implementing the human rights of citizens.

Both the 1945 Constitution and Law No. 39 of 1999 have regulated and guaranteed human rights, especially civil and political rights. The suffrage of citizens in the General Election is one of the most important substances that must be guaranteed and protected by its existence as a constitutional right of citizens which is a manifestation of the guarantee of the rights of political rights, which in turn will strengthen the existence of democracy. Thus, it can be said that human rights and elections are both interrelated, mutually reinforcing and influencing each other.

A free and fair election is an important pillar of democracy, because from it a government will be produced with strong political legitimacy from the people. Therefore, the general election must guarantee the participation of all people directly. Non-democratic elections will result in the absence of legitimacy and popular support for the government. This is stated in the Declaration of Principles for Election Observation that:

Genuine democratic elections are a requisite condition for democratic governance, because they are the vehicle through which the people of a country freely express their will, on a basis established by law, as to who shall have the legitimacy to govern in their name and in their interests. Achieving genuine democratic elections is a part of establishing broader processes and institutions of democratic governance. ${ }^{5}$

Elections are positively correlated with human rights in three important aspects, namely (1) the right to take part in government; (2) the right to vote and to be elected; and (3) the right

${ }^{3}$ Yusdar. (2010). Penggunaan Kartu Tanda Penduduk, Kartu Keluarga dan Paspor Sebagai Tanda Pemilih Dalam Rangka Pemilihan Umum di Indonesia (Studi Kasus Putusan Mahkamah Konstitusi No. 102/PUU-VII/2009). Jurnal Konstitusi. Vol.I No.1, November 2010. p. 12.

${ }^{4}$ Hadiz, V. (2003). Reorganizing political power in Indonesia: A reconsideration of so-called'democratic transitions'. The Pacific Review, 16(4), 591-611.

${ }^{5}$ Declaration of Principles for Election Observation and Code of Conduct for International Election Observers, Commemorated October 27, 2005, at the United Nations, New York, dari http://www.idea.int/resources/analysis/observation_coc.cfm, accessed on 21 March 2011. 
to equal access to public service. With this rationale, the election must be carried out in accordance with international standards and in fact normatively it is affirmed through Perpres No. 6 of 2013 concerning Ratification of the International Statute of Democracy and Election Aid.

The Statute, known as the Stockholm Statute in 1995 and later revised in 2006 and effective in 2008, in its consideration emphasizes that democracy is essential for promoting and guaranteeing human rights and that participation in political life, including government, is part of human rights, classified and guaranteed by international treaties and declarations.

\section{Former Prisoners and Suspect Rights in Elections: Judging from the Human Rights Perspective}

Douglas W. Rae argues that an electoral system will work well if it is divided into 3 (three) phases in which each phase is important to note. These phases include: First, balloting or voting as a specification of the voter people' role in deciding whether to participate in the elections or not. Second, districting as a restricting factor in translating votes into seats; and Third, the electoral formula as determinant factor in translating votes into seats.

As above view that the concept of democracy in general elections has a requirement, that democracy only means if people have the opportunity to accept or reject the person or group of people who lead it. The opportunity to accept or reject it can only be done through general elections. Therefore, the general elections actually are an absolute requirement (conditio sine qua non) for the organizing of governance based on the principle of representative. ${ }^{6}$

General election activity is also a most fundamental means of distributing human rights. Therefore, in the framework of the implementation of the citizen' human rights, it is imperative for the government to guarantee the implementation of the general election in accordance with the predetermined administration schedule, as argued by Asshiddiqie, ${ }^{7}$ that:

"As the principle of people sovereignty in which the people are sovereign, all aspects of the holding of the elections must also be returned to the people to decide it. It becomes a violation of human rights if the government does not guarantee the holding of elections, delaying the holding of the elections without consent of representatives, or do nothing so that elections are not held properly."

For instance, it is different with Jean Bodien that sovereignty is often interpreted as "supreme authority", a full and supreme authority within a State to regulate its entire territory without interference from the governments of other States. However, the theory of sovereignty is rejected by political-pluralism thought, according to Jean Boedin that theory of sovereignty is a narrow view and not based on strong reasons for rejecting a pluralist society. None of these groupings can take precedence or higher than others. To these problems arise several theories that give answers, each gives rise to a theory or doctrine of sovereignty.

Hence, general election is a realization of the fulfillment of civil and political rights. This right is guaranteed not only in international human rights law, as stipulated in Article 21 of the UN UDHR and Article 25 of the ICCPR, it is also constitutionally guaranteed through the provisions of Article 22E and Article 28D paragraph (3) of the 1945 Constitution, Law No. 12 of 2005 concerning the Ratification of the ICCPR and the provisions of Article 23 paragraph (1) of Law No. 39 of 1999 concerning human rights.

\footnotetext{
${ }^{6}$ Prihatmoko, J.J. (2003). Pemilu 2004 dan Konsolidasi Demokras. LP21 Press: Semarang, p.41

${ }^{7}$ Asshiddiqie, J. (2006). Pengantar Ilmu Hukum Tata Negara. Jilid II. Konstitusi Press: Jakarta. p. 172.
} 
The 1945 Constitution in Article 28D Paragraph (1) states that: "Every person has the right to a just recognition, guarantee, protection, and legal certainty and equal treatment before the law". This article shows that the state will treat every citizen equally and fairly by promoting equality before the law. Subsequently Law No. 39 of 1999 Article 3 paragraph (2) states that every person has the right to recognition, guarantees, protection and fair legal treatment and to obtain legal certainty and equal treatment before the law.

On the contrary, KPU Regulation Number 3 of 2017 concerning the Nomination of Governors and Deputy Governors, Regents and Deputy Regents, Mayors and Deputy Mayors. Article 4 KPU Regulation No. 3 of 2017 states, "Never as a convicted person based on a court ruling that has obtained a permanent legal decision, convicted of minor negligence (culpa levis), convicted for political reasons, convicted person who is not serving a sentence in prison is openly and honestly tells the public that the person in question is serving a sentence not in prison ".

Although according to the provisions of Article 23 paragraph (1) of Law Number 39 of 1999 stated that "Everyone is free to vote and have political confidence". Furthermore, according to the provisions of Article 43 paragraph (1) of Law Number 39 of 1999, it is stated that "Every citizen has the right to be elected and elected in general elections based on equal rights through direct, public, free, confidential, honest and fair voting in accordance with the laws and regulations". The two provisions of the article above clearly indicate that there is an inherent juridical guarantee for every Indonesian citizen himself to exercise his right to vote. ${ }^{8}$

In fact, the General Election Supervisory Body (hereinafter, Bawaslu) stated that there were 199 former convicts of corruption cases registered as candidates for provincial, district and city candidates. They are registered with each political party to contest the 2019 General Election. Of the 199 details, 30 former corruption prisoners registered as candidates for DPRD candidates in 11 provinces, 148 former corruption prisoners registered as candidates for DPRD candidates in 93 districts, and 21 former corruption prisoners registered as prospective DPRD candidates in 12 cities. $^{9}$

From the document of recapitulation of legislative candidates of former prisoners of corruption received, Bawaslu did not disclose the names and political parties carrying 199 former corruptors as the candidates. Bawaslu only details the distribution of ex-prisoners of corruption registered.

The regulations and their implementation guarantee the implementation of human rights, especially civil and political rights. For example, there is a guarantee of equal rights or nondiscrimination (free from discrimination in race, color, sex, religion, language, nationality or social origin). Likewise, there is a guarantee of freedom of opinion, association, and assembly, movement, guarantee of the right to security, and proper legal process. Therefore, elections have a positive relationship with the development of democracy, if political parties as constituents are given the guarantee of competing to obtain the people's votes (voters).

The right to vote for citizens in the General Election is one of the most important substances that must be guaranteed and protected by its existence as a constitutional right of citizens which is a manifestation of the guarantee of political rights. Where both will strengthen the existence of democracy.

${ }^{8}$ Fuady, M. (2011). Teori Negara Hukum Modern (Rechtstaat). Bandung: Refika Aditama, p. 1-2.

9 CNN Indonesia. Bawaslu: 199 Mantan Koruptor Daftar Caleg DPRD. Available online at: https://www.cnnindonesia.com/nasional/20180726075228-32-317061/bawaslu-199-mantankoruptor-daftar-caleg-dprd July 26, 2018. 
As a result, it can be concluded that both human rights and elections are interrelated to strengthen and influence each other. Election progress will strengthen human rights (political rights) of every citizen where the election is a manifestation of the guarantee of human rights (political rights) of citizens. In the context of a democratic country both are elements and support for the existence of a democratic state.

\section{Conclusion}

The General Election is a manifestation of the political rights of the people to determine the course of government and the functions of the State guaranteed by the constitution. These political rights are the fundamental rights of the people. Therefore, the implementation of the General Election, in addition to embodying the sovereignty of the people, is also a means of implementing the human rights of citizens (constitutional rights). The right to vote for citizens in the General Election is one of the most important substances that must be guaranteed and protected by its existence as a constitutional right of citizens which is a manifestation of the guarantee of political rights. Where both will strengthen the existence of democracy. As a result, it can be concluded that both human rights and elections are interrelated to strengthen and influence each other. Election progress will strengthen human rights (political rights) of every citizen where the election is a manifestation of the guarantee of human rights (political rights) of citizens.

\section{References}

[1]. Aspinall, E., \& Mietzner, M. (Eds.). (2010). Problems of democratization in Indonesia: elections, institutions and society. The National Bureau of Asian Research. Institute of Southeast Asian Studies.

[2]. Asshiddiqie, J. (2006). Pengantar Ilmu Hukum Tata Negara. Jilid II. Konstitusi Press: Jakarta.

[3]. CNN Indonesia. Bawaslu: 199 Mantan Koruptor Daftar Caleg DPRD. Available online at: https://www.cnnindonesia.com/nasional/20180726075228-32-317061/bawaslu-199-mantankoruptor-daftar-caleg-dprd July 26, 2018.

[4]. Declaration of Principles for Election Observation and Code of Conduct for International Election Observers, Commemorated October 27, 2005, at the United Nations, New York, dari http://www.idea.int/resources/analysis/observation_coc.cfm, Accessed on 21 March 2011.

[5]. Fuady, M. (2011). Teori Negara Hukum Modern (Rechtstaat). Bandung: Refika Aditama.

[6]. Hadiz, V. (2003). Reorganizing political power in Indonesia: A reconsideration of socalled'democratic transitions'. The Pacific Review, 16(4), 591-611.

[7]. Prihatmoko, J.J. (2003). Pemilu 2004 dan Konsolidasi Demokras. LP21 Press: Semarang.

[8]. Surbakti, R. (2014). Understanding the Flaws in Indonesia's Electoral Democracy, dalam Strategic Review, The Indonesian Journal of Leadership, Policy and World Affairs, Volume 4, Number 1 January-March 2014.

[9]. Yusdar et al. (2010). Penggunaan Kartu Tanda Penduduk, Kartu Keluarga dan Paspor Sebagai Tanda Pemilih Dalam Rangka Pemilihan Umum di Indonesia (Studi Kasus Putusan Mahkamah Konstitusi No. 102/PUU-VII/2009). Jurnal Konstitusi. Vol.I No.1, November 2010. 